\title{
Spatial Analysis in GIS for Planning Regional in Supporting the Superior Food Commodities
}

\author{
Nurmiaty ${ }^{1}$, Samsu Arif ${ }^{2}$, Sukmawati ${ }^{3}$, Rahmad D. ${ }^{1}$, Andi Ridwan ${ }^{1}$, Miss Rahma Yassin ${ }^{1}$, and Yunarti ${ }^{1}$ \\ "Department of Estate Crops Cultivation, Pangkep State Polytechnic of Agriculture, Makassar, Indonesia \\ ${ }^{2}$ Departement of Geophysics, Hasanuddin University, Makassar, South Sulawesi, Indonesia \\ ${ }^{3}$ Faculty of Agriculture, Animal Husbandry, and Fisheries, Universitas Muhammadiyah Parepare, South \\ Sulawesi, Indonesia
}

\begin{abstract}
Article Info
Volume 7, Issue 5

Page Number: 273-281

Publication Issue :
\end{abstract}

September-October-2020

\section{Article History}

Accepted : 01 Oct 2020

Published : 05 Oct 2020

\section{ABSTRACT}

The development of sustainable superior food commodities requires planning that can accelerate competitiveness and regional potential in the form of spatial-based data. This research will determine the leading commodities of the food crops sub-sector in Pangkep Regency, South Sulawesi. The data used are secondary data series of crop area in the period 2014-2018 and primary land suitability data. The analysis was carried out in two stages: i) suitability analysis of superior commodities which included conformity analysis with commodity regional map, matching sector analysis (LQ), employer absorption analysis (Shift Share), analysis of marketing coverage ii) Analysis of selected superior commodities will be developed using 3 stages of analysis, namely: 1) identification of commodities cultivated in the sub-district, 2) analysis of the economic value of superior commodities (LQ analysis, differential shift analysis, trend analysis), 3) determining superior commodities according to economic value analysis. The results of the study showed there are three main commodities, namely paddy, maize and soybeans, food sub-sector commodities and the area obtained through the process of overlaying land suitability data using GIS. The overlay results obtained an area of paddy development area of 6,440 ha, maize covering an area of 5,103 ha, and soybean covering an area 2,762 ha. The results are presented in the form of regional maps that are very detailed and effective in providing information about superior commodities and their suitability for their distribution areas.

Keywords: Land Suitability, Base Sector, Labor, Marketing to Reach

\section{INTRODUCTION}

The development of sustainable superior food commodities requires planning that can accelerate competitiveness and regional potential in the form of spatial-based data $[1],[2],[3],[4],[5],[6]$. The specifications for the development of superior food commodities must be in accordance with the 
characteristics of the agroecosystem and the dominance of the people's griculture. This is closely related to the analysis of resources, socio-economic and spatial planning. Feasibility of a superior commodity biologically if attempted in accordance with the agroecology zone; socially feasible if able to provide business opportunities, can be done and accepted by the local community so that it has an impact on employment; and economically feasible if it is profitable.

Various approaches and analytical tools have been widely used to identify superior commodities, using several technical and non-technical criteria in the framework of meeting the aspects of supply and demand. One approach that can be used to initiate superior commodities is the Location Quotient (LQ) method [7]. A lot of research has been done on superior commodities, but the determination of superior commodities using Location Quotient (LQ) or Shift Share Analysis (SSA) analysis, has not been linked to land suitability using GIS. Agricultural development as a leading sector uses LQ [8] analysis, superior food based on LQ and SSA, horticultural commodities(Sukmawani, et al., 2014) while agroecosystem-based LQ and SSA approaches are reported [10]. Making decisions on rational and sustainable land can be done using GIS [11] because it involves the analysis and interpretation of biophysical and socio-economic data, statistics, both spatial and temporal. GIS analysis produces information products in the form of maps, tables, and textual reports for decision making at various application scales. The latest spatial analysis tool of spatial analysis makes it easy to access data and information. In this study, we applied the latest spatial analysis tool in analysis the superior food commodities.

The advantages of this research are using four approaches to developing superior commodity areas, namely: 1) agroecosystem approach, (land suitability based on FAO processed by GIS), 2) agribusiness system approach (LQ and SSA), 3) participatory approach (FGD), and 4) approach integrated (GIS). The results are presented in the form of regional maps that are very detailed and effective in providing information about superior commodities and their suitability for their distribution areas.

\section{METHODS AND MATERIAL}

\section{A. Suitability Analysis of Leading Commodities}

Suitability analysis of superior commodities is an analysis to determine whether a commodity is able to be a driver of agriculture-based economic growth (agribusiness) in an integrated and sustainable manner (Fig. 1).

1) Land suitability analysis with commodity area map (Matching): Identification of commodity suitability based on land suitability criteria. Land suitability is based on spatial analysis of food crops and land physical limiting factors both physical and chemical properties of the soil. The result is a land suitability map for food crops with criteria, very appropriate, quite appropriate and marginal accordingly.

2) Base sector analysis (LQ) LQ analysis is used to determine the superiority over food crop commodities that have advantages with LQ criteria $>1$ indicated the commodity becomes a base or becomes a source of growth. Commodities have comparative advantages, the results not only meet the needs in the region concerned but also exported to the outside region. The data used in this analysis are data harvested area series for 5 years from 2014 to 2018. LQ results based on aspects of harvested area can meet superior criteria from the supply side, because the harvest area is the resultant suitability of growing plants with agroecology conditions that implicit include elements (variables) of the climate, the physiography and the soil type [7], which are formulated as follows: 


$$
L Q=(p i / p t) /(P i / P t)
$$

where: pi is harvested area of commodity $i$ at subdistrict level, pt is the total harvested area of all commodities at the sub-district level, $\mathrm{Pi}$ is the total harvested area of commodity i at district level, $\mathrm{Pt}$ is the total commodity harvested area at district level.

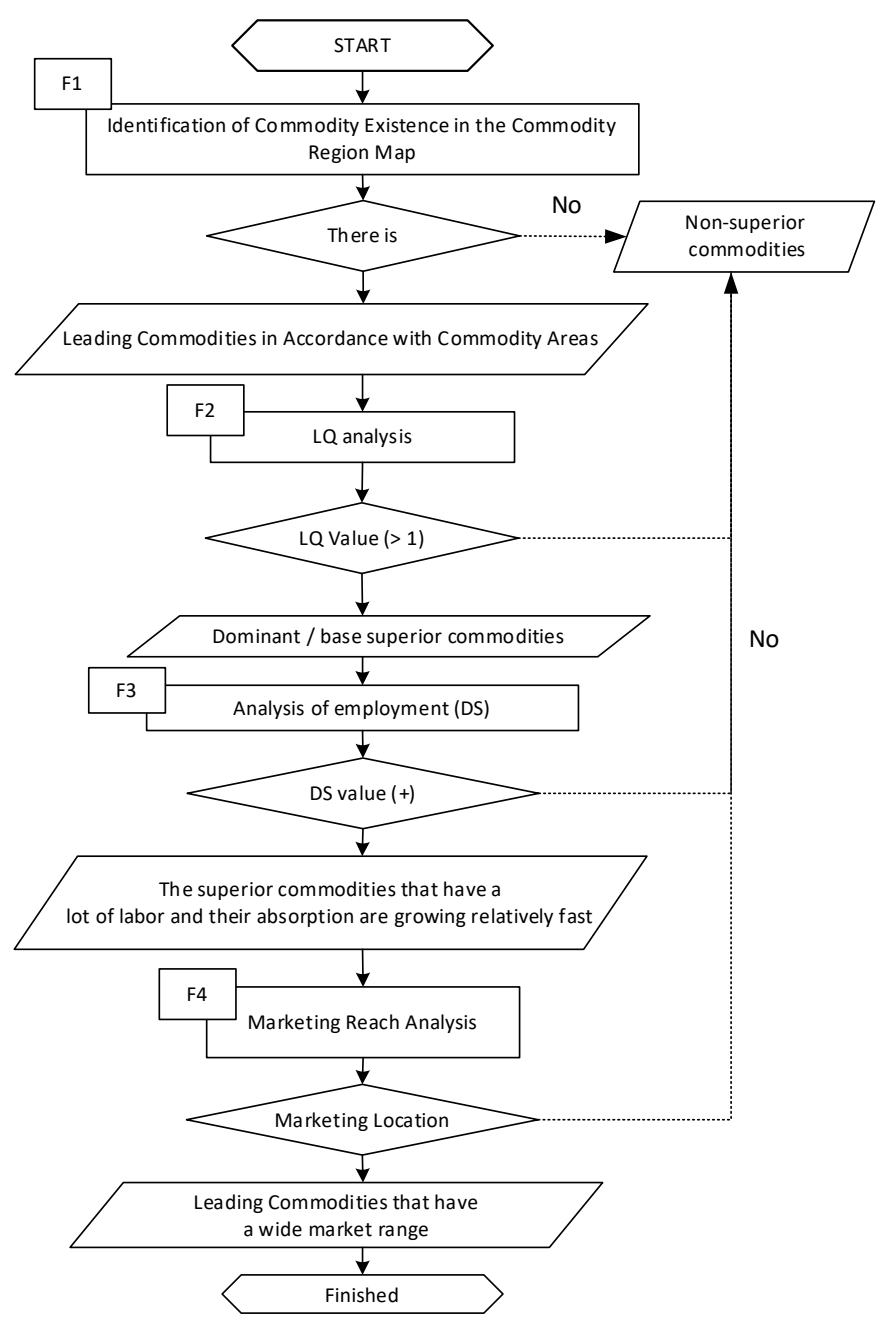

Figure 1: Flowchart for supporting decision in identification of the superior food commodity

3) Analysis of employer absorption (Shift Share): Shift share analysis (SSA) is used to calculate commodity advantages in terms of employment. The assessment criteria are positive (+) and negative (-). Formulate mathematically as follows [10]:

$$
\mathrm{SSA}=\left(\frac{\mathrm{X} . .(\mathrm{t} 1)}{\mathrm{X} . .(\mathrm{t} 0)}-1\right)+\left(\frac{\mathrm{Xi}(\mathrm{t} 1)}{\mathrm{Xi}(\mathrm{t} 0)}-\frac{\mathrm{X} . .(\mathrm{t} 1)}{\mathrm{X} . .(\mathrm{t} 0)}\right)+\left(\frac{\mathrm{Xij}(\mathrm{t} 1)}{\mathrm{Xij}(\mathrm{t} 0)}-\frac{\mathrm{Xi}(\mathrm{t} 1)}{\mathrm{Xi}(\mathrm{t} 0)}\right)
$$

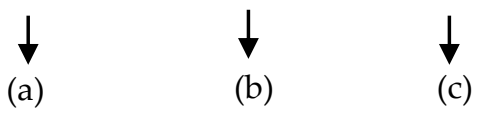

where: (a) is regional share component (sub-district), (b) is proportional shift component (district), (c) is component differential shift, $\mathrm{X}$.. is the total activity value in the total region, $\mathrm{Xi}$ is the total value of a particular activity in the total area, $\mathrm{Xij}$ is value of a particular activity in certain area units, t0 is starting point of year, and $\mathrm{t} 1$ is the last year point.

4) Analysis of marketing range: Marketing analysis is used to identify superior commodities that have a broad marketing range of the district.

\section{B. Analysis of the Selection Commodities and the District Socio-Economic Empowerment (PSE)}

Analysis of the selection of superior commodities and locations that are in line with the district PSE is carried out to find the superior food commodities of the sub-district, distribution analysis to determine the location of commodity distribution and assessment of alignment with the district PSE. The results obtained are the selection of three priority food commodities: paddy, maize, soybean, the sub-district as the development location along with the appropriate area, based on GIS analysis in the form of a regional map.

Identification is carried out on the types of food commodities cultivated in each sub-district and district, including the aspects of production and the price of each commodity. The data used is data series from 2014-2018 obtained from the Pangkep Regency statistics agency.

Economic analysis of superior commodities uses LQ analysis, shift differential and trend analysis. Commodities that meet the criteria are LQ economic 
value $>1$, differential shift positive economic value $(+)$ and have a trend of increasing (positive) production.

Determination of superior food commodities is chosen based on average economic value of 5 years which are sorted throuh the highest to the lowest value of all types of food commodities.

The selection of superior food commodities was determined based on the commodity suitability analysis in the RTRW, land suitability analysis based on GIS production of agricultural commodities in Pangkep district. The data was analyzed based on LQ SSA, marketing to reach, production trend and average value of commodity production for 5 years using production data from 2014-2018. The results of this analysis are then adjusted to the results obtained at the forum discussion group (FGD).

\section{RESULTS AND DISCUSSION}

\section{A. Land-suitability analysis for food commodities}

1) Land suitability analysis with commodity area map (Matching): Analysis of land suitability for food commodities in Pangkep Regency is shown in Table 1.

\section{TABLE 1. ANALYSIS OF LAND SUITABILITY OF FOOD CROPS SUB-SECTORS IN PANGKEP REGENCY (S1, VERY SUITABLE; S2, SUITABLE: S3 MARGINAL SUITABLE; N, NON SUITABLE)}

\begin{tabular}{|c|c|c|c|c|}
\hline \multirow{2}{*}{$\begin{array}{c}\text { Food crop } \\
\text { commodities }\end{array}$} & \multicolumn{4}{|c|}{ Land Suitability (ha) } \\
\hline & S1 & S2 & S3 & $\mathbf{N}$ \\
\hline Paddy & 4,597 & 43,043 & 7,95 & 23,582 \\
\hline Maize & 0 & 4,543 & 44,529 & 29,962 \\
\hline Soybeans & $\begin{array}{r}10,59 \\
5\end{array}$ & 35,175 & 8,834 & 24,43 \\
\hline Total & $\begin{array}{r}15,19 \\
2\end{array}$ & 82,761 & 61,313 & 77,974 \\
\hline
\end{tabular}

The results of land-suitability analysis based on FAO Method (1976), showed the class of land suitability for the widest rice plant in S2 class (43.043 ha), Corn on class S3 (44.529 ha), and soybean in S2 class (35.175 ha). Special corn plants are not found the land that has the class of land suitability $\mathrm{S} 1$, this is a matter of limiting the boundary factor salinity and the abundance of rocks. The results of the analysis are also shown in the form of diagram pie as shown in Figure 2. The broad spatial distribution of landsuitability class based on Table 1 is shown in Figure 3.

2) Base sector analysis (LQ): The main commodities (LQ value > 1) for the food crops sub-sector in Pangkep Regency are paddy, maize, soybeans, peanuts and cassava. Commodities with an LQ value of 1 become the basis of growth, where yields can meet local areas and can be offered [7]. Therefore it is necessary to increase productivity in the districts as presented in Table 1. Paddy and maize crops are the basis of trade in all sub-districts in Pangkep Regency. At present, paddy and maize are commodities that are widely developed in rotation in paddy fields. While maize is widely developed in dry land areas because it has a high adaptation to drought conditions. Maize cultivation in wetlands has more in the dry season in the dry land in the rainy season [12]. Soybean development can be a priority choice in the districts of Balocci, Bungoro, Segeri and Tondong Tallasa. 


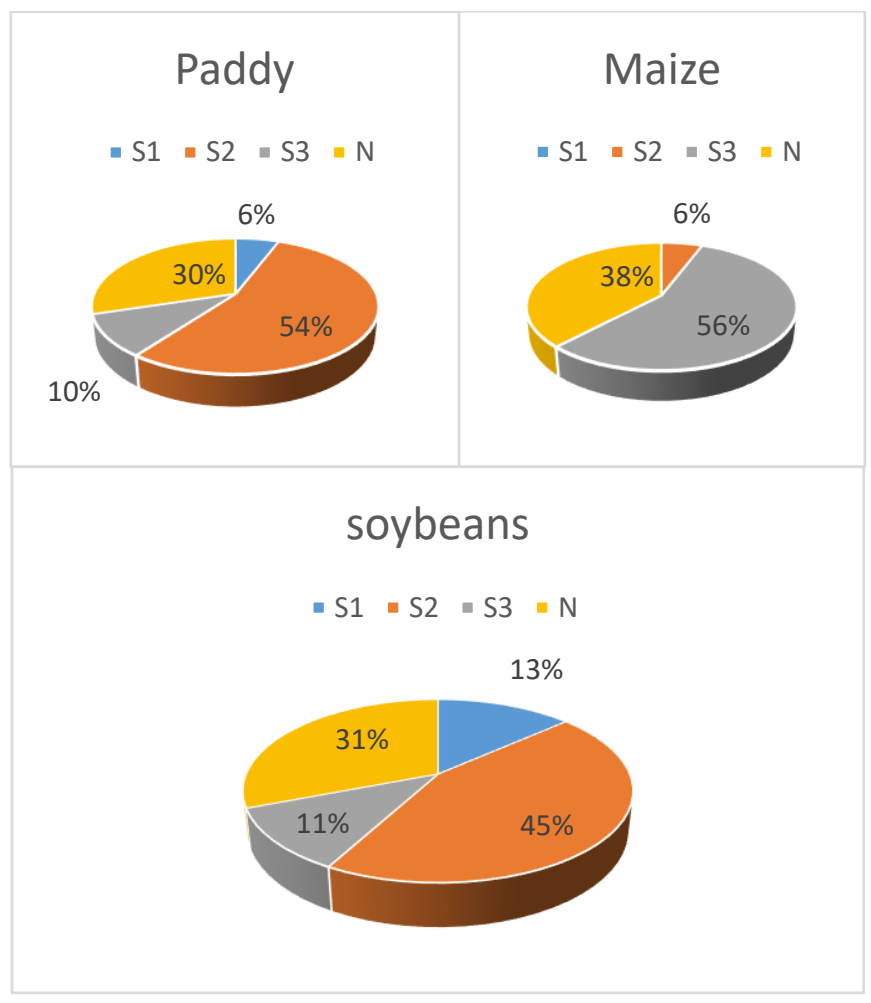

Figure 2: Pie diagram of land suitability for food crops in Pangkep Regency
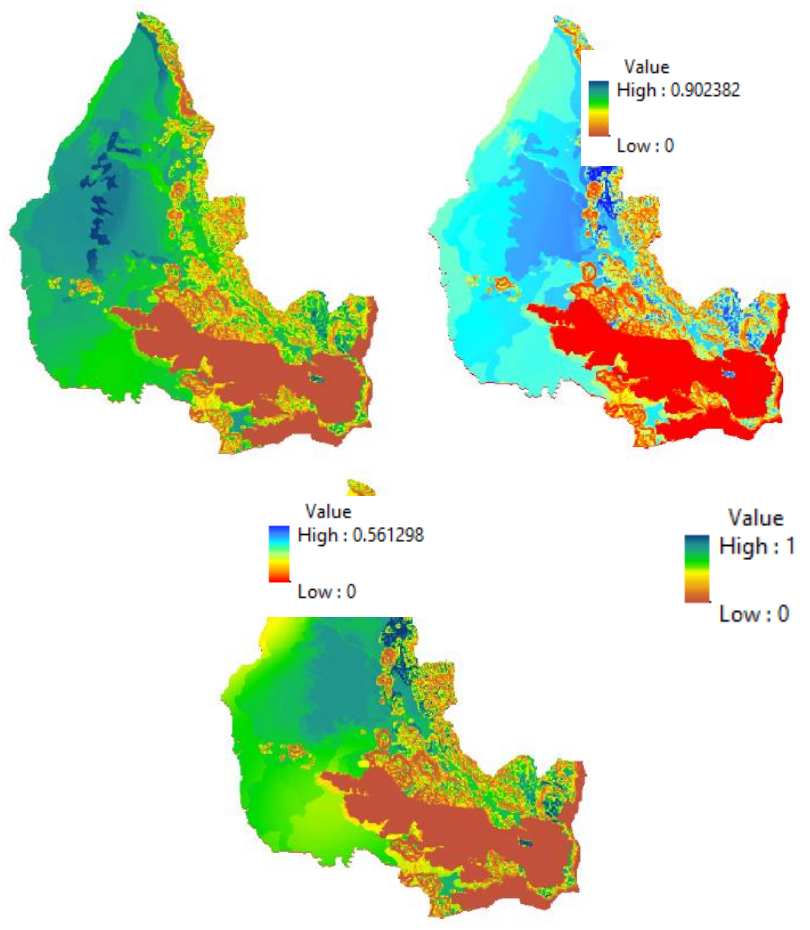

Figure 3: Map of land suitability for food crops in

Pangkep Regency for paddy (left), maize (right), soybean (below). Range land suitability index from 0 (lowest) to 1 (highest),

$\mathrm{S} 1$ is $0.75-1.00, \mathrm{~S} 2$ is $0.5-0.75, \mathrm{~S} 3$ is $0.25-0.5$

3) Analysis of employer absorption (Shift Share: The results of the analysis of employment absorption show that paddy and maize are widely cultivated by the community at large in Pangkep District (see Table 3). While soybeans are only cultivated widely in Balocci District. The green beans are mostly cultivated in Mandalle District. One of the factors that influence the increase in maize productivity in dry land is the allocation of labor, because the addition of $\mathrm{HOK} /$ ha will reduce production by $2,855 \mathrm{~kg}$ [13].

TABLE 2

ANALYSIS OF LQ OF SUB-SECTOR OF FOOD CROPS FOR SEVERAL DISTRICT IN PANGKEP REGENCY

\begin{tabular}{lccc}
\hline \multirow{1}{*}{ District } & \multicolumn{3}{c}{ LQvalue } \\
\cline { 2 - 4 } & Paddy & Maize & $\begin{array}{c}\text { Soybea } \\
\text { ns }\end{array}$ \\
\hline Balocci & 0.94 & 1.15 & 6.02 \\
Bungoro & 1.02 & 0.33 & 1.62 \\
Labakkang & 1.03 & 0.45 & - \\
Mandalle & 1.02 & 0.66 & - \\
Ma'rrang & 1.02 & 0.67 & - \\
Minasatene & 1.01 & 0.90 & - \\
Pagkajene & 1.05 & 0.02 & - \\
Segeri & 0.92 & 3.40 & 0.11 \\
Tondongtallasa & 0.94 & 1.51 & 5.12 \\
\hline
\end{tabular}

Table 3

analyzes the employment of food crops sub-sectors for several district in Pangkep Regency

\begin{tabular}{lrrr}
\hline \multirow{2}{*}{\multicolumn{1}{c}{ District }} & \multicolumn{3}{c}{ DS Value } \\
\cline { 2 - 4 } & \multicolumn{1}{c}{ Paddy } & \multicolumn{1}{c}{ Maize } & \multicolumn{1}{c}{ Soybeans } \\
\hline Balocci & & 0.011725 & 0.194763 \\
Bungoro & 0.000009 & & $(0.005831)$ \\
Labakkang & $(0.000003)$ & & \\
Mandalle & 0.000067 & & \\
Ma'rrang & 0.000170 & & \\
Minasatene & 0.000021 & & \\
Pangkajene & 0.000021 & & \\
Segeri & & 0.015467 & \\
Tondongtallasa & & 0.003811 & 0.005951 \\
\hline
\end{tabular}


4) Analysis of marketing range: The results of the analysis of the marketing range for paddy, maize and soybean commodities have a market reach to outside the district (see table 4). Sustainable production provides opportunities for the development of derivative products from each competition, such as the manufacture of processed maize, soybeans and peanuts. Opportunities for maize demand are not only limited to large domestic needs, but also for export purposes (Susanto \& Sirappa, 2005). Increased productivity provides a dominant contribution $(0.85 \%$ / year) to the increase in demand for maize for the feed industry is increasing fast enough. Table 4 Analysis of the marketing range of the food crops subsector in Pangkep District.

\section{B. Selection of Leading Commodities and \\ Distribution Locations in line with the District \\ Socio-Economic Empowerment (PSE)}

1) Identification of commodities cultivated in each sub-district: The results agreed with the competition conducted in each sub-district in Pangkep Regency, discussing with the presentation of the value of the sub-district's production towards the district's production value. These results indicate an increase in production results due to competition in the district area. For example, soybean production in Balocci District contributes a production value of $40.83 \%$ to the total production value of the district. While paddy production is contributed by almost every district to district production. However, the biggest contributors were Labakkang and Minasatene districts. Segeri District is the biggest contributor to maize production, which is $42.60 \%$ of the production as shown in Table 5.
TABLE 4

MARKETING REACH OF THE FOOD CROP SUB SECTOR FOR SEVERAL DISTRICT IN PANGKEP REGENCY

\begin{tabular}{lcl}
\hline District & Commodities & Marketing location \\
\hline Balocci & Maize & $\begin{array}{l}\text { outside the district } \\
\text { Soybean } \\
\text { outside the district }\end{array}$ \\
Bungoro & Paddy & $\begin{array}{l}\text { outside the district } \\
\text { Mandalle }\end{array}$ \\
Paddy & outside the district \\
Marrang & Paddy & outside the district \\
Minasatene & Paddy & outside the district \\
Pangkajene & Paddy & outside the district \\
Segeri & Maize & outside the district \\
Tondong & Maize & outside the district \\
Tallasa & Soybean & outside the district \\
\hline
\end{tabular}

TABLE 5

PERCENTAGE OF PRODUCTION VALUES OF FOOD CROPS FOR EACH SUB-DISTRICT TO THE TOTAL PRODUCTION VALUE FOR SEVERAL DISTRICT IN PANGKEP REGENCY

\begin{tabular}{lccc}
\hline \multirow{2}{*}{ District } & \multicolumn{3}{c}{$\begin{array}{c}\text { Percentage of district production value } \\
\text { to district (\%) }\end{array}$} \\
\cline { 2 - 4 } & Paddy & Maize & Soybeans \\
\hline Balocci & 6.36 & 7.80 & 40.83 \\
Bungoro & 13.70 & 4.38 & 21.86 \\
Labakkang & 17.90 & 7.73 & - \\
Mandalle & 8.23 & 5.29 & - \\
Marrang & 8.59 & 5.65 & - \\
Minasatene & 17.76 & 15.82 & - \\
Pangkajene & 9.32 & 0.18 & - \\
Segeri & 11.59 & 42.60 & 1.44 \\
Tondong & 6.56 & 10.55 & 35.87 \\
Tallasa & & & 100.00 \\
Total & 100.00 & 100.00 & \\
\hline
\end{tabular}

2) Analysis of the economic value of superior commodities: Sector base analysis (LQ) based on the economic value of the subdistrict production compared to the economic value of the district. The results obtained are presented in Table 6. Based on the economic value of food commodities, paddy is a base commodity in Pangkep district. This is seen from 
the results of paddy production which is used as the main indicator in the calculation. The yield component is the final resultant of the whole process of crop cultivation [14]. All commodities have LQ > 1 values so that they will be analyzed using differential shift analysis (see Table 6).

TABLE 6

ANALYSIS OF LQ PRODUCTION VALUES AND PRICES OF FOOD COMMODITIES FOR SEVERAL DISTRICT IN

PANGKEP REGENCY

\begin{tabular}{lccc}
\hline \multirow{2}{*}{ District } & \multicolumn{3}{c}{ LQ Value } \\
\cline { 2 - 4 } & Paddy & Maize & Soybeans \\
\hline Balocci & 0.94 & 1.15 & 6.02 \\
Bungoro & 1.01 & 0.58 & 1.61 \\
Labakkang & 1.05 & 0.45 & - \\
Mandalle & 1.03 & 0.66 & - \\
Ma'rrang & 1.02 & 0.67 & - \\
Minasatene & 1.01 & 0.90 & - \\
Pagkajene & 1.05 & 0.02 & - \\
Segeri & 0.90 & 3.32 & - \\
Tondongtallasa & 0.93 & 1.50 & 5.10 \\
\hline
\end{tabular}

Employer analysis to determine the leading commodities is based on the difference in production of districts per year for five years compared to the difference in district production to get a positive value of DS. Determination of superior commodities based on LQ analysis does not take into account the land area for a commodity farming, but rather emphasizes the tendency towards increasing harvested area and production [14], so that further analysis is needed on employment. As an example of paddy, although the land suitability analysis is in the marginal fit category (see Table 1) so that the growth of paddy plants is limited to certain areas, this commodity is still widely cultivated by the community, Pangkep Regency, especially in Bungoro, Labakkang, Marrang and Segeri Districts. Therefore, increasing productivity of paddy plants is influenced by the availability of labor, starting at the stage of cultivation, harvest and post- harvest. Labor is needed at the stage of fertilizing land cultivation, eradicating pests and weeding, harvesting, drying and transporting production. While maize plants are cultivated widely in Bungoro, Mandalle and Segeri Districts. The soybean commodity is cultivated by the people in Balocci, Bungor and Tondong Tallasa Districts. (Table 7).

\section{TABLE 7}

ANALYSIS OF EMPLOYMENT OF FOOD COMMODITIES

BASED ON PRODUCTION VALUES AND PRICES OF FOOD COMMODITIES FOR SEVERAL DISTRICT IN PANGKEP REGENCY

\begin{tabular}{lrrr}
\hline \multirow{2}{*}{ District } & \multicolumn{3}{c}{ DS Value } \\
\cline { 2 - 4 } & \multicolumn{1}{c}{ Paddy } & \multicolumn{1}{c}{ Maize } & Soybeans \\
\hline Balocci & 0.000002 & 1.384016 & 0.000249 \\
Bungoro & 0.000002 & & 0.000249 \\
Labakkang & $(0.000002)$ & $(0.027600)$ & \\
Mandalle & 0.000012 & $(0.009102)$ & \\
Ma'rrang & 0.000005 & 0.012201 & $(0.032204)$ \\
Minasatene & $(0.000009)$ & 0.036439 & \\
Pagkajene & $(0.000002)$ & $(0.010771)$ & \\
Segeri & & -0.056861 & \\
Tondong & & & \\
Tallasa & 0.000008 & 0.014122 & 0.002607 \\
\hline
\end{tabular}

Analysis of production trends is carried out because there are more than three commodities with positive DS (+) values. It is important to look at growth trends in the amount of each commodity over the past 5 (five) years. The highest average paddy production was found in five districts, namely Bungoro, Labakkang, Minasatene and Segeri. (see Table 8). Maize production trends are found in Labakkang, Minasatene, Segeri and Tondong Tallasa districts. The increase in soybean production occurred in Bungoro and Tondong Tallasa sub-districts. 
TABLE 8

ANALYSIS OF TRENDS IN FOOD COMMODITIES FOR SEVERAL DISTRICT IN PANGKEP REGENCY

\begin{tabular}{lrrr}
\hline \multirow{1}{*}{ District } & \multicolumn{3}{c}{ Trend } \\
\cline { 2 - 4 } & Paddy & Maize & $\begin{array}{r}\text { Soyb } \\
\text { eans }\end{array}$ \\
\hline Balocci & 635 & 191 & $(128)$ \\
Bungoro & 2,526 & 191 & 157 \\
Labakkang & 3,193 & 245 & - \\
Mandalle & 1,900 & 89 & $(7)$ \\
Ma'rrang & 1,647 & 139 & $(10)$ \\
Minasatene & 2,992 & 286 & - \\
Pagkajene & 1,602 & $(3)$ & - \\
Segeri & 2,386 & 749 & - \\
Tondongtallasa & 1,310 & 224 & 56 \\
\hline
\end{tabular}

3) Selected Featured Commodities and Development Areas: The selection of superior commodities is determined based on the analysis of the suitability of commodities in the RTRW, the production of agricultural commodities in Pangkep regency, which are analyzed based on LQ analysis, labor absorption (differential shift), marketing reach, production trends and the average value of commodity production for 5 years using production data from 2011-2015. Access to consumer demand; access to service work; and housing affordability combined in the spatial equilibrium model used to calculate econometric factor effects [15]

The results of this analysis are then adjusted to the results obtained at the Forum Discussion Group (FGD), in order to obtain results as presented in Figure 4.

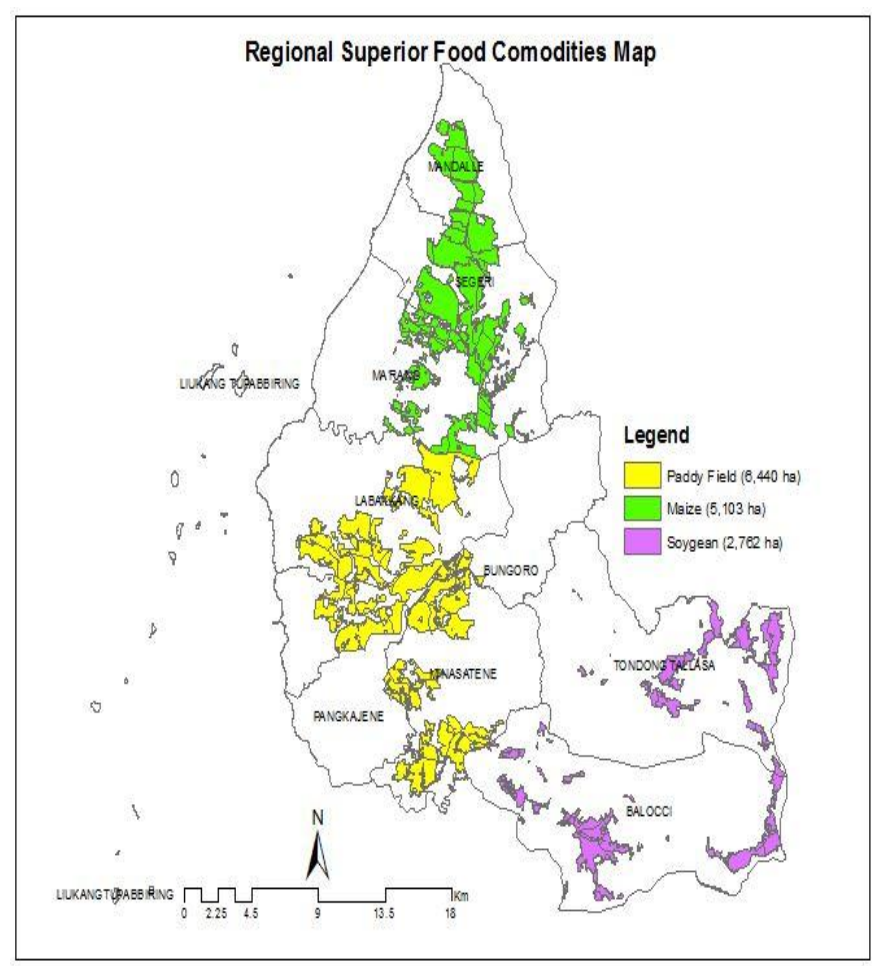

Figure 4: Map of development of regional superior commodities in Pangkep Regency

\section{CONCLUSION}

a. Paddy , maize and soybeans are the main commodities in Pangkep Regency .

b. Paddy crop development is directed at four subdistricts , namely Pangkajene, Minasate'ne , Bungoro and Labakkang with a total area of development of 6,440 ha

c. Maize cultivation is directed at three districts , namely Ma'rang, Segeri and Mandalle with a total development area of 5,103 ha .

d. The development of soybean plants is directed at two districts, namely Balocci and Tondong Tallasa with a development area of 2.762 ha .

\section{ACKNOWLEDGEMENTS}

The authors are deeply thankful to the DRPM DIKTI (through the PSNI research grand), Pangkep Regency government (Bappeda Pangkep), and Pangkep State 
Polytechnic of Agriculture for providing data, fund, and other supporting facilities in this study.

\section{REFERENCES}

[1]. S. Baja, Nurmiaty, and S. Arif, "GIS-based soil erosion modeling for assessing land suitability in the urban watershed of tallo river, South Sulawesi, Indonesia," Mod. Appl. Sci., vol. 8, no. 4, pp. 50-60, 2014.

[2]. S. Baja, R. Neswati, and S. Arif, "Land use and land suitability assessment within the context of spatial planning regulation," in IOP Conference Series: Earth and Environmental Science, 2018, vol. 157 , no. 1 .

[3]. D. Läpple, A. Renwick, J. Cullinan, and F. Thorne, "What drives innovation in the agricultural sector? A spatial analysis of knowledge spillovers," Land use policy, vol. 56, pp. 238-250, 2016.

[4]. Nurmiaty and S. Baja, "Spatial Based Assessment of Land Suitability and Availability for Maize ( Zea mays L .) Development in Maros Region, South Sulawesi , Indonesia," Open J. Soil Sci., vol. 3, pp. 244-251, 2013.

[5]. Nurmiaty and S. Baja, "Using fuzzy set approaches in a raster GIS for land suitability assessment at a regional scale: Case study in maros region, indonesia," Mod. Appl. Sci., vol. 8, no. 3, pp. 115125, 2014.

[6]. Nurmiaty, S. Baja, S. Arif, A. Ridwan, D. Rahmad, and Sukmawati, "Developing Agricultural Land Geospatial Information in Supporting Regional Food Resilience," in IOP Conference Series: Earth and Environmental Science 279, 2019.

[7]. R. Hendayana, "Aplikasi Metode Location Quotient (LQ) dalam Penentuan Komoditas Unggulan Nasional," J. Inform. Pertan., vol. 12, no. Desember 2003, pp. 1-21, 2003.

[8]. A. T. Basuki, "Strategi Pengembangan Sektor Pertanian Pasca Gempabumi Kabupaten Bantul," J. Ekon. dan Stud. Pembang., vol. 9, no. 1, pp. 1125, 2008.
[9]. R. Sukmawani, M. Haeruman, L. Sulistyowati, and T. Perdana, "Papaya Development Model As A Competitive Local Superior Commodity Model Pengembangan Pepaya Sebagai Komoditas Unggulan Lokal Yang Berdaya Saing," vol. 15, no. 50, pp. 128-140, 2014.

[10]. J. Mulyono and Munibah Khursatul, "The Use of Location Quotient and Shift Share Analysis in the Determination of Leading Food Crops in Bantul Regency," J. Inform. Pertan., vol. 25, no. 2 Desember, pp. 221-230, 2016.

[11]. Sombroek and J. Antonie', "The use of geogrophic information systems (GIS) in land resources appraisal," OutlookonAgriculture, vol. Vol. 23.NO, 1994.

[12]. S. Nurwahidah, "Analisis Komparasi Usahatani Jagung Lahan Sawah Dan Lahan Kering Di Kabupaten Sumbawa," vol. XVI, no. 2, pp. 118128, 2014.

[13]. M. S. Lalu and Syuryawati, "Faktor-faktor yang Mempengaruhi Usahatani Jagung di Lahan Sawah dan Lahan Kering," Balai Penelit. Tanam. Serelia, vol. 20, no. 1, pp. 81-90, 2017.

[14]. A. N. Susanto and M. P. Sirappa, "Prospek dan strategi pengembangan jagung untuk mendukung ketahanan pangan di Maluku," J. litbang Pertan., vol. 24, no. 2, pp. 70-79, 2005.

[15]. A. E. Andersson, D. Emanuel, Z. Daghbashyan, and B. Hårsman, "Location and spatial clustering of artists," Reg. Sci. Urban Econ., vol. 128-137, no. 128-137, 2013.

Cite this article as : Nurmiaty, Samsu Arif, Sukmawati, Rahmad D., Andi Ridwan, Miss Rahma Yassin, Yunarti, "Spatial Analysis in GIS for Planning Regional in Supporting the Superior Food Commodities", International Journal of Scientific Research in Science and Technology (IJSRST), Online ISSN : 2395-602X, Print ISSN : 2395-6011, Volume 7 Issue 5, pp. 273-281, September-October 2020. Available at

doi : https://doi.org/10.32628/IJSRST207562

Journal URL : http://ijsrst.com/IJSRST207562 